\title{
The initiation of the southern central Great Barrier Reef: New multiproxy data from Pleistocene distal sediments from the Marion Plateau (NE Australia)
}

\author{
Nathalie Dubois ${ }^{\mathrm{a}, *}$, Pascal Kindler ${ }^{\mathrm{a}}$, Silvia Spezzaferri ${ }^{\mathrm{b}}$, Stjepan Coric $^{\mathrm{c}}$ \\ ${ }^{a}$ Section of Earth Sciences, University of Geneva, Rue des Maraîchers 13, 1205 Geneva, Switzerland \\ b Department of Geosciences, University of Fribourg, Ch. du Musée 6, 1700 Fribourg, Switzerland \\ ${ }^{\mathrm{c}}$ Geological Survey of Austria, Neulingstrasse 38, 1030 Vienna, Austria
}

\begin{abstract}
Significant synchronous shifts in the chemistry, mineralogy, grain sizes and color of the sediments at $6 \mathrm{~m}$ below sea floor (mbsf) at ODP Site 1195 on the Marion Plateau (NE Australia) are interpreted to reflect a major regional paleoceanographic change: the initiation of the southern province of the Great Barrier Reef (GBR). The onset of this massive carbonate production centre nearby resulted primarily in increased deposition of carbonate-rich sediments of neritic origin. Both sedimentation rate and terrigenous input record a coincident decline attributed to inshore trapping of materials behind the reefs. Our best estimate places the development of reef framework in the southern part of the GBR between 560 and $670 \mathrm{kyr}$ B.P., based on an age model combining magnetostratigraphic and biostratigraphic data. The proposed estimation agrees with previous studies reporting an age between 500 and 930 kyr B.P., constraining more tightly their results. However, it does not support research placing the birth of the GBR in Marine Isotope Stage (MIS) 11 ( $400 \mathrm{kyr})$, nor the theory of a worldwide modern barrier reef development at that time.
\end{abstract}

Keywords: Great Barrier Reef; Pleistocene reef development; mixed carbonate-siliciclastic sediments; Marion Plateau; carbonate sedimentology

\section{Introduction}

The Great Barrier Reef (GBR) is the largest reef system on Earth, extending for roughly $2000 \mathrm{~km}$ from $9^{\circ} \mathrm{S}$ to $24^{\circ} \mathrm{S}$. It is located on the northeastern Australian continental margin, the largest modern mixed carbonate-siliciclastic depositional system. Understanding its evolution provides information on similar environments that have existed during the past as well as clues to the current issues of sea level fluctuation and climate change (Braithwaite et al., 2004). Research has been conducted for more than a decade to study and date the onset of the GBR

\footnotetext{
* Corresponding author. Present address: Department of Oceanography, Dalhousie University, 1355 Oxford Street, Halifax, Nova Scotia, Canada B3H 4J1. Tel.: +1 902402 4195; fax: +1 9024943877.

E-mail addresses: nathalie.dubois@dal.ca (N. Dubois), pascal.kindler@terre.unige.ch (P. Kindler), silvia.spezzaferri@unifr.ch (S. Spezzaferri), stjepan.coric@geologie.ac.at (S. Coric).
}

on the Australian continental margin, however, its development remains poorly understood (Alexander et al., 2001; Webster and Davies, 2003). Varying ages have been proposed for its initiation, but the latest studies agree on a young feature that emerged during the Neogene (Davies et al., 1987; Peerdeman et al., 1993; Alexander et al., 2001; Lawrence and Herbert, 2005). Davies et al. (1987) suggest that initial reef growth becomes younger from North to South.

Ocean Drilling Program (ODP) Leg 133 was conducted in 1990 to study the initiation, growth and demise of carbonate platforms and specifically the central region of the GBR. Sixteen holes (Sites 811-826) were drilled on the Queensland and Marion Plateaus, in the Queensland and Townsville Troughs and on the GBR. Paleontological dating of seismic reflectors beneath the reef sequence at Sites 819 through 821 (Fig. 1) led Davies et al. (1991) to suggest that the GBR is younger than $930 \mathrm{kyr}$, and possibly as young as 500 kyr. In the same cores, Feary et al. 


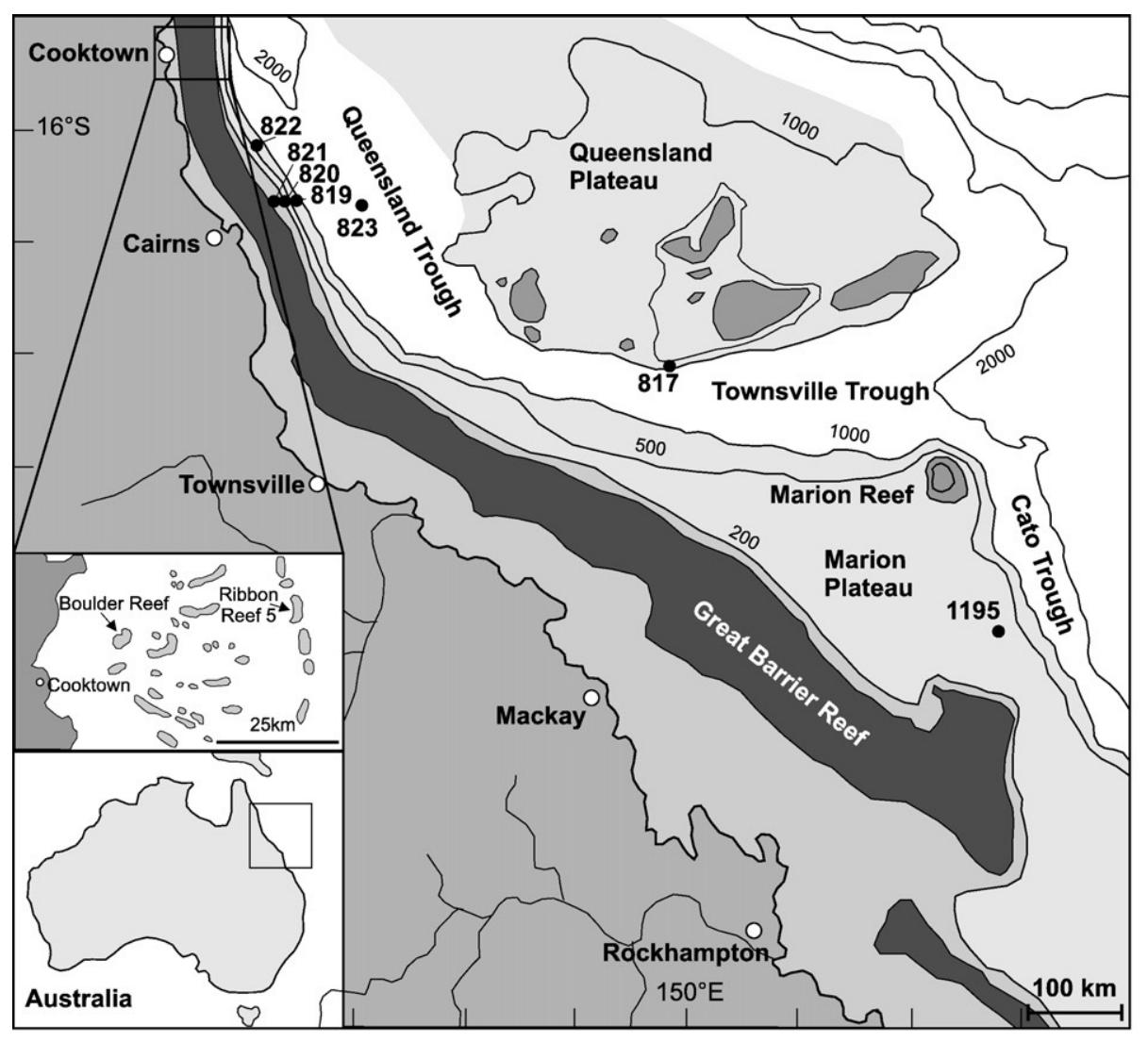

Fig. 1. The position of the GBR relative to bathymetry and main physiographic features of northeast Australia. Marked are the positions of drilling Sites $817,819,820$, 821, 822 and 823 from ODP Leg 133, Site 1195 from ODP Leg 194 as well as Boulder Reef and Ribbon Reef 5. Areas of modern reef development on the Queensland and Marion Plateaus are marked with dark shading, and the extensive area of the Great Barrier Reef is indicated in dark grey.

(1993) interpreted a marked reduction in sedimentation rate between $760 \mathrm{kyr}$ and $1.01 \mathrm{Myr}$ B.P as due to the growth of the GBR, creating a barrier that trapped sediments inshore. However, this estimate is based on three nannofossil datum points at 465, $930 \mathrm{kyr}$ and 1.10 Myr B.P., and assuming constant sedimentation rates, which the authors themselves describe as a "questionable assumption". In contrast, Peerdeman et al. (1993) suggest that the growth of the GBR might coincide with a shift in the frequency of their planktonic foraminiferal $\delta^{18} \mathrm{O}$ record in Hole $820 \mathrm{~A}$ that corresponds to both a marked temperature variation and changes in depositional style at about $400 \mathrm{kyr}$ B.P. However, their age model, based on graphic correlation with the isotope stratigraphy from two deep sea cores from the equatorial Pacific (Core V28-239 and Hole 677A) was inconsistent with the nannostratigraphy, and had to be adapted for the upper part of the hole. Davies and MacKenzie (1993) interpreted an increase in carbonate deposition at Site 822 (Fig. 1) as the initiation of the GBR. This shift in sedimentation corresponds to three events at Site 823 in the basin (Fig. 1) attributed to Marine Isotope Stage (MIS) 10 (360 kyr B.P.) through at least MIS 16 (> 660 kyr B.P.). However, their research consists of a crude event stratigraphy based on sea level variations, and thus is not supported by a strong age model. Similarly, Cotillon et al. (1994) record an increase in the platform-carbonate flux at Site 817 (Fig. 1) shortly before $500 \mathrm{kyr}$ B.P., and attribute it to bioconstructed banks which preceded the GBR. Subsequently, they record a decrease of carbonate flux from 500 kyr B.P. that they correlate either to the mid-Brunhes dissolution event or to the entrapping of materials behind the GBR.

To refine the existing age estimate, two boreholes were drilled in 1995 by the International Consortium for Great Barrier Reef Drilling in the reefs east of Cooktown, one on the inner-shelf (Boulder Reef) and one on the outer-shelf margin (Ribbon Reef 5) (Fig. 1). Preliminary results, based on strontium isotope composition and magnetostratigraphy assume the onset of full reef conditions at $600 \pm 280 \mathrm{kyr}$ B.P. (Alexander et al., 2001). However, the analytical precision achievable in Pleistocene strata by the Sr isotope method is insufficient to discriminate this value from their second result of $720 \pm 280 \mathrm{kyr}$ B.P. Recently, research on the Ribbon Reef 5 core led Braithwaite et al. (2004) to suggest an oldest limit for the first establishment of the reef framework in this area in MIS 11 (about 400 kyr B.P.). This age is based on depositional units formed by sea level variations, but is again not tightly constrained. Carbonate deposition - indicated by the presence of corals in slope deposits in the bottom part of the core - began in that area already $\sim 770 \mathrm{kyr}$ B.P. However, the authors regard the onset of the GBR sensu stricto as indicated by the presence of a well-developed shallow reef with a high number and diversity of corals in the core examined. Note that the latter two studies are the only ones that examined the onset of reef growth in-situ, compared to all other studies that attribute changes in 
downslope sediments to the establishment of reefal framework, i.e. the birth of the GBR.

In conclusion, we note that earlier studies have poor age controls and most of them examined cores drilled in a proximal position (inner shelf, outer shelf, shelf edge), in the northern part of the central GBR. In contrast, here we present a multiproxy study on periplatform and hemipelagic sediments from ODP Site 1195 on the Marion Plateau (Fig. 1). The Marion Plateau lies directly east of the southern central GBR, forming an extension of the Australian continental margin. It accumulates carbonate material from the pelagic rain and from the Great Barrier or local detached reefs, as well as terrigenous material from the Australian landmass (Isern et al., 2002; Page and Dickens, 2005). Modern reef growth on this plateau is restricted to the Marion Reef on the north-eastern corner and to the Saumarez Reef on the south-eastern margin. Two large carbonate platform complexes started on the Marion Plateau in the early Miocene, but became inactive by the end of the middle Miocene (Isern et al., 2002) and early Pliocene (Kindler et al., 2006). Leg 194 was conducted in 2001 to constrain the carbonate platform history and the magnitude and timing of sea level changes on the Marion Plateau. We have analyzed the two upper cores of Hole 1195A, the most distal drilling site of Leg 194, for distribution of bulk carbonate content, X-ray mineralogy, grain size, physical properties, oxygen isotope ratios, and have characterized the origin of phosphorus in the sediments in an attempt to decipher the onset of the GBR system nearby.

\section{Materials and methods}

Sediment cores from Hole 1195A were recovered during the ODP Leg 194 in 2001 (Isern et al., 2002). These consist of pale yellow skeletal packstone and grainstone, usually well-sorted and with abundant well-preserved foraminifers. Hole 1195A (Marion Plateau, 20²4' S, 152 $40^{\prime}$ E, $422 \mathrm{~m}$ water depth) was sampled from $14.07 \mathrm{~m}$ below sea floor (mbsf) to $0.03 \mathrm{mbsf}$, at roughly $35 \mathrm{~cm}$ intervals, yielding a total of 40 samples (Table 1). All samples, approximately $5 \mathrm{~cm}^{3}$ each, were subsequently divided into subsamples.

\subsection{Sedimentological analysis}

Calcium carbonate concentrations were determined using the carbonate-bomb method (Müller and Gastner, 1971) and a sample size of $0.7 \mathrm{~g}$. Duplicate analyses and comparison with a laboratory standard place the error of reported carbonate content values within $\pm 2 \%$. Every second subsample was crushed to powder using an agate mortar for X-ray diffraction (XRD) analysis, to determine bulk mineralogy and in particular the different carbonate phases present. The samples were analyzed by Bernard Grobéty at the University of Fribourg, Switzerland, using a Philips PW1710 X-ray diffractometer operating at $40 \mathrm{kV}$ and $40 \mathrm{~mA}$. Diffractograms were recorded with $0.02^{\circ}$ steps between $3^{\circ}$ and $65.2^{\circ}$, with a counting time of $1 \mathrm{sec} / \mathrm{step}$ and a scanning speed of $1 \% \mathrm{~min}$. Relative abundance of the phases was quantified by Rietveld analysis of the diffractograms with the program SIROQUANT (Taylor, 1991). Grain size distributions in three size classes $(<125 \mu \mathrm{m}, 125-250 \mu \mathrm{m}$,
Table 1

Sample depth, composition determined from XRD-mineralogy, and abundance of $\mathrm{T}$. tosaensis

\begin{tabular}{|c|c|c|c|c|c|c|c|}
\hline \multirow[t]{2}{*}{ Sample } & \multirow{2}{*}{$\begin{array}{l}\text { Depth } \\
\overline{(\mathrm{mbs} f)}\end{array}$} & \multirow{2}{*}{$\begin{array}{l}\text { Quartz } \\
\text { (wt.\%) }\end{array}$} & \multirow{2}{*}{$\begin{array}{l}\text { Calcite } \\
(\text { wt.\%) }\end{array}$} & \multirow{2}{*}{$\begin{array}{l}\mathrm{Mg}- \\
\text { Calcite } \\
\text { (wt.\%) }\end{array}$} & \multirow{2}{*}{$\frac{\text { Aragonite }}{(\text { wt. } \%)}$} & \multirow{2}{*}{$\frac{\text { Kaolinite }}{(\text { wt. \%) }}$} & \multirow{2}{*}{$\begin{array}{l}T . \\
\text { tosaensis } \\
\text { (\%-tot) }\end{array}$} \\
\hline & & & & & & & \\
\hline 1 & 0.03 & & & & & & 0.00 \\
\hline 2 & 0.12 & 0.00 & 46.90 & 20.80 & 29.30 & 0.00 & 0.00 \\
\hline 3 & 0.51 & & & & & & 0.00 \\
\hline 4 & 0.88 & 4.70 & 40.70 & 20.10 & 20.20 & 9.30 & 0.00 \\
\hline 5 & 1.26 & & & & & & 0.00 \\
\hline 6 & 1.62 & 0.00 & 51.20 & 22.00 & 21.00 & 0.00 & 0.00 \\
\hline 7 & 2.02 & & & & & & 0.00 \\
\hline 8 & 2.38 & 1.50 & 49.30 & 29.30 & 18.60 & 0.00 & 0.00 \\
\hline 9 & 2.73 & & & & & & 0.00 \\
\hline 10 & 3.06 & 1.70 & 55.40 & 23.40 & 16.00 & 0.00 & 0.00 \\
\hline 11 & 3.47 & & & & & & 0.00 \\
\hline 12 & 3.88 & 0.00 & 40.50 & 40.40 & 6.00 & 0.00 & 0.23 \\
\hline 13 & 4.07 & 0.00 & 64.90 & 24.50 & 7.00 & 0.00 & 0.73 \\
\hline 14 & 4.42 & & & & & & 0.58 \\
\hline 15 & 4.78 & 0.00 & 67.30 & 8.60 & 19.10 & 0.00 & 0.78 \\
\hline 16 & 5.18 & & & & & & 1.54 \\
\hline 17 & 5.57 & 0.00 & 85.80 & 0.00 & 10.30 & 0.00 & 0.00 \\
\hline 18 & 5.93 & & & & & & 0.96 \\
\hline 19 & 6.28 & 0.00 & 83.10 & 0.00 & 10.00 & 0.00 & 4.22 \\
\hline 20 & 6.68 & & & & & & 2.25 \\
\hline 21 & 7.07 & 4.10 & 74.30 & 0.00 & 6.00 & 10.70 & 8.40 \\
\hline 22 & 7.43 & & & & & & 7.54 \\
\hline 23 & 7.78 & 2.40 & 84.80 & 0.00 & 8.30 & 0.00 & 9.93 \\
\hline 24 & 8.18 & & & & & & 10.36 \\
\hline 25 & 8.57 & 2.30 & 82.00 & 0.00 & 5.30 & 7.60 & 7.12 \\
\hline 26 & 8.93 & & & & & & 6.98 \\
\hline 27 & 9.28 & 1.70 & 80.70 & 0.00 & 9.00 & 3.50 & 11.65 \\
\hline 28 & 9.68 & & & & & & 13.48 \\
\hline 29 & 10.07 & 4.20 & 89.10 & 0.00 & 3.90 & 0.00 & 14.37 \\
\hline 30 & 10.43 & & & & & & 12.73 \\
\hline 31 & 10.78 & 1.20 & 87.40 & 0.00 & 0.00 & 0.00 & 23.33 \\
\hline 32 & 11.18 & & & & & & 16.39 \\
\hline 33 & 11.57 & 5.20 & 74.20 & 0.00 & 5.20 & 11.40 & 11.97 \\
\hline 34 & 11.93 & & & & & & 15.41 \\
\hline 35 & 12.28 & 2.00 & 78.80 & 0.00 & 3.50 & 6.00 & 9.12 \\
\hline 36 & 12.68 & & & & & & 21.01 \\
\hline 37 & 13.07 & 1.50 & 85.70 & 0.00 & 7.70 & 0.00 & 14.48 \\
\hline 38 & 13.43 & & & & & & 16.01 \\
\hline 39 & 13.78 & 2.00 & 86.10 & 0.00 & 6.20 & 0.00 & 16.43 \\
\hline 40 & 14.07 & & & & & & 12.85 \\
\hline
\end{tabular}

and $>250 \mu \mathrm{m}$, separated by wet sieving) were determined by dry weight.

\subsection{Nannoplanktonic fauna}

Every sample was analyzed for nannoplankton. Smear slides were used to examine calcareous nannoplankton by light microscopy (transmitted light and crossed nicols) at a magnification of $1000 \times$. Total abundance was estimated on a single field view, whereas species abundances were studied on at least 20 fields of view on each sample.

\subsection{Stable isotopes}

In each sample, fifteen calcite tests of the white variety of the planktonic foraminifer $G$. ruber were analyzed for their oxygen 
isotopic composition. In order to reduce size-related isotope ratio variability, the tests were selected microscopically in the $250-350 \mu \mathrm{m}$ size fraction. Tests were cleaned ultrasonically in distilled water to remove fine-fraction contamination prior to isotopic analysis. The analyses were performed by Torsten Venneman at the University of Lausanne, Switzerland, on a Finnigan-MAT DeltaPlus XL mass spectrometer coupled to a GasBench II. Data are reported in standard delta notation as the per mil (\%) difference from the Vienna Pee Dee Belemnite (VPDB) standard. The reproducibility of multiple analyses of NBS-19 relative to an internal working standard was $<0.1 \%$.

\subsection{Phosphorus content}

The characterization of the different sedimentary phosphorus phases was conducted on dry-sieved $<125 \mu \mathrm{m}$ subsamples, using a 4-step sequential extraction technique adapted from the SEDEX method (Ruttenberg, 1992; Anderson and Delaney, 2000). Operationally defined detrital (det-P) and organic-bound phosphorus (org-P) were determined.

\subsection{Core physical properties}

High resolution physical property logs were taken aboard the JOIDES Resolution during ODP Leg 194 (Isern et al., 2002). Bulk density, bulk magnetic susceptibility and natural gamma radiation (NGR) were measured on whole cores with a multisensor track system (MST). The archive halves of split cores were used for sediment color scans using a Minolta CM2002 spectrophotometer and for paleomagnetic data using a threeaxis pass-through cryogenic magnetometer (Isern et al., 2002).
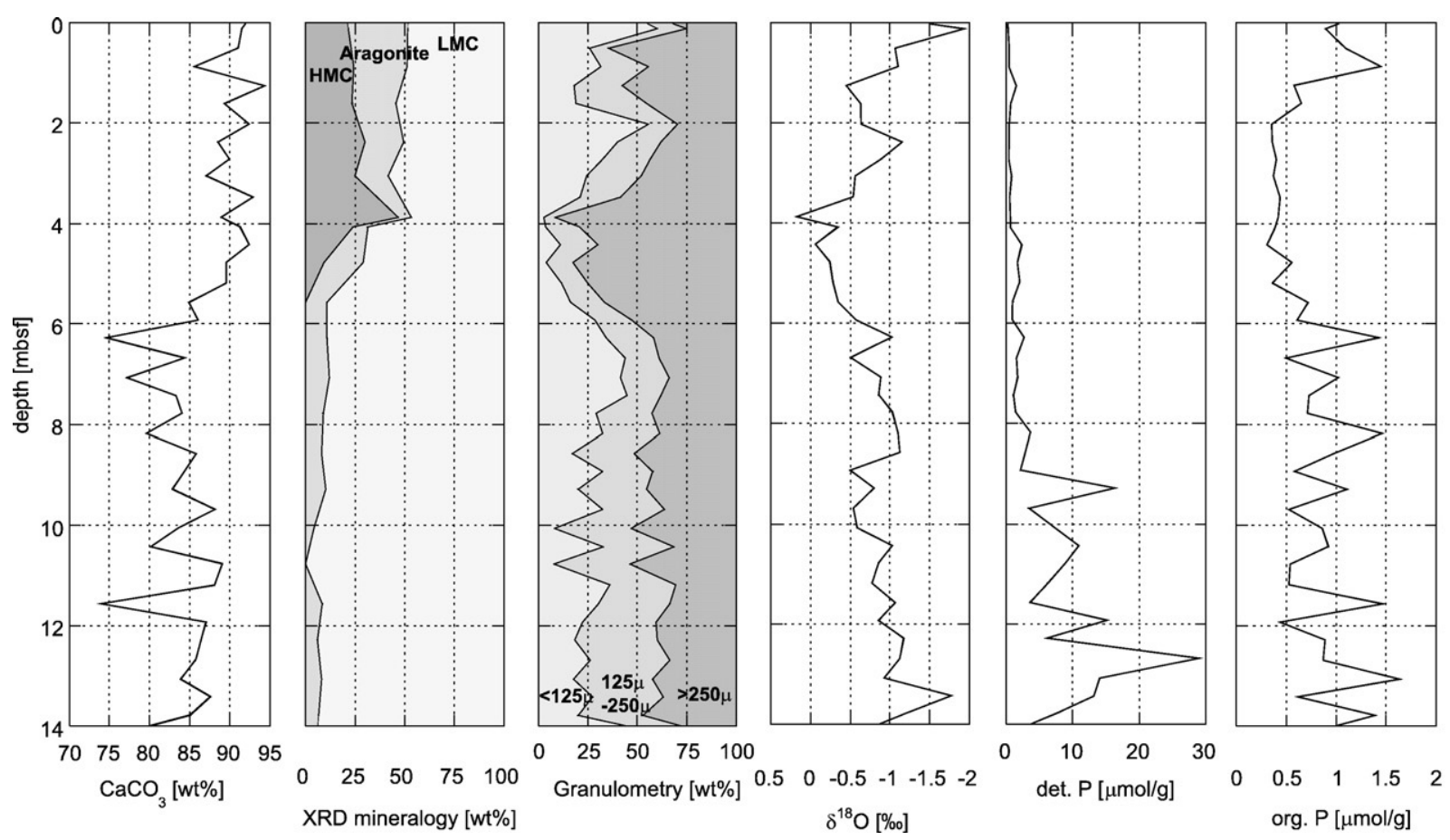

Fig. 2. Depth profiles [mbsf] for Site 1195. A) Bulk carbonate content [wt.\%]. B) Percentages of carbonate minerals obtained from XRD mineralogy [wt.\%]. C) Granulometry [wt.\%]. D) Oxygen isotopic data [\%o] relative to V-PDB for G. ruber. E) Concentration of detrital phosphorus [ $\mu$ molP/g. sediment]. F) Concentration of organic-bound phosphorus $[\mu \mathrm{molP} / \mathrm{g}$. sediment].

\section{Results}

\subsection{Sedimentology}

All sediments analyzed are predominantly composed of pelagic carbonates (foraminifers and nannofossils) with lesser amounts of bioclastic debris derived from neritic areas.

Carbonate content at Hole 1195A varies from 74 to 92 wt.\% (Fig. 2), with most of the samples containing $>80 \mathrm{wt} . \%$. The section below 6 mbsf contains less carbonate, with a mean value of $83.4 \pm 2.7 \mathrm{wt} . \%$, compared to the upper part with a mean value of $90.0 \pm 4.6$ wt. $\%$.

XRD analyses confirmed the carbonate analysis. The mineralogy of the sediments at Hole 1195A comprises aragonite, lowmagnesian calcite (LMC), high-magnesian calcite (HMC), quartz and kaolinite (Table 1). Below 6 mbsf, LMC represents generally 90 wt. $\%$ of the carbonate minerals (Fig. 2) and HMC minerals are absent. Above 4 mbsf aragonite and HMC together represent 50 wt.\% of the carbonate minerals. Quartz is present in every sample analyzed below $7 \mathrm{mbsf}$, but is sparse in the upper part of the Hole (Table 1).

The grain size spectrum records two important increases in the proportion of the coarser fraction $(>250 \mu \mathrm{m})$. This usually represents $40 \mathrm{wt} . \%$ of the total sediment, but it shifts to a mean value of $70 \mathrm{wt} . \%$ between $6.3 \mathrm{mbsf}$ and $2.7 \mathrm{mbsf}$, and to a mean value of 53 wt.\% between $1.7 \mathrm{mbsf}$ and $0.3 \mathrm{mbsf}$ (Fig. 2).

\subsection{Faunal results}

All samples contain abundant and well-preserved calcareous nannoplankton with little or no dissolution or overgrowth. 
Results are presented in Table 2 as follows: abundant (a) $=$ more than 10 specimens occurring per field; common (c) $=1-10$ specimens per field; few (f) $=1$ specimen per $1-10$ fields; rare $(r)=1$ specimen per more than 10 fields.

All samples contain high percentages of Florisphaera profunda. The last occurrence (L.O.) of Pseudoemiliania lacunosa is situated between 4.78 and 4.42 mbsf. Based on the presence of this form, the lower part of the studied core interval can be attributed to nannoplankton Zone NN19. According to Lourens et al. (2004), the L.O. of P. lacunosa occurs at $440 \mathrm{kyr}$ B.P. The interval between 4.4 and $2.0 \mathrm{mbsf}$ is characterized by the absence of Emiliania huxlei and $P$. lacunosa and can be attributed to Gephyrocapsa oceanica Zone (NN20). The first occurrence (F.O.) of E. huxlei occurs at $1.6 \mathrm{mbsf}$, and is placed at $290 \mathrm{kyr}$ B.P. (Lourens et al., 2004). The uppermost part of the investigated section can thus be attributed to nannoplankton Zone NN21 (Martini, 1971).

Two additional biohorizons are identified in the planktonic foraminiferal fauna, composed of 30 tropical and subtropical species: the L.O. of Truncorotalia tosaensis (650 kyr B.P.) between 5.93 and 5.57 mbsf (Berggren et al., 1995), and the L.O. of Globigerinoides ruber — pink variety (120 kyr B.P. in the Indo-Pacific region) between 1.62 and 1.26 mbsf (Thompson et al., 1979). A small number of T. tosaensis shells were found above this limit, probably due to reworking of the sediment or to confusion with corroded T. truncatulinoides shells (Table 1).

\subsection{Geochemistry}

Oxygen isotope ratios measured on $G$. ruber range from $+0.18 \%$ o to $-1.95 \%$ (Fig. 2 ). The mean $\delta^{18} \mathrm{O}$ value is $-0.81 \%$. The $\delta^{18} \mathrm{O}$ record shows a minimum interval starting at $6.3 \mathrm{mbsf}$ and lasting until $2.4 \mathrm{mbsf}$.

Phosphorus phases represent only a small fraction of the total sediment, but variations in the concentration of operationally defined det-P and org-P are significant. Det-P shows a mean concentration of $4.4 \mu \mathrm{mol} \mathrm{P} / \mathrm{g}$ sed. (Fig. 2), while org-P is less common with a mean of only $0.78 \mu \mathrm{mol} \mathrm{P} / \mathrm{g}$ sed. (Fig. 2). Det-P shows a sharp and pronounced decrease at $9 \mathrm{mbsf}$, above this depth values are less than $5 \mu \mathrm{mol} \mathrm{P} / \mathrm{g}$ while beneath they show important variability, ranging from 4 to $29 \mu \mathrm{mol} / \mathrm{g}$. Org-P shows large amplitude variations between 14 and 6 mbsf, with values ranging between 0.4 and $1.6 \mu \mathrm{mol} \mathrm{P/g}$, while a characteristic interval is recorded from 6.0 to $1.2 \mathrm{mbsf}$, with values of approximately $0.3 \mu \mathrm{mol} \mathrm{P} / \mathrm{g}$.

\subsection{Physical properties}

The NGR depth-profile (Fig. 3) records a mean value of $18 \mathrm{cps}$ and high amplitude variations in the lower $8 \mathrm{~m}$ of the core. Above $6 \mathrm{mbsf}$, the mean value decreases to $2.5 \mathrm{cps}$ and the record shows small amplitude variations with the exception of one distinct peak between 2 and 4 mbsf (>20 cps).

ODP uses the CIE 1976 L*a*b* color description system, in which $\mathrm{L}^{*}$ denotes the sediment lightness $(\%)$, and $\mathrm{a}^{*}$ and $\mathrm{b}^{*}$ are color reflectance parameters. a* denotes the red-green chromaticity (positive values indicating red color, negative values indicating green color) and $b *$ denotes yellow-blue chromaticity (positive values indicating yellow color, negative value indicating blue color). At 6 mbsf, sediment lightness L* (Fig. 3) shows a shift from low frequency cyclic variations in the lower part to high frequency variations, while the $\mathrm{a}^{*} / \mathrm{b} *$ ratio (Fig. 3) records a shift to higher values above 6 mbsf. According to the ODP physical properties handbook, ratios such as $a^{*} / b^{*}$ may differentiate between variations such as those in clay mineralogy or nannofossil content better than the parameters $a^{*}$ and $b^{*}$ alone. Looked at separately, both parameters record a shift to higher values at this depth. This corresponds to more yellowish and reddish sediments in the upper part of Hole 1195A. This shift in color was described and reported in the visual core descriptions filed by the shipboard scientific party aboard the Joides Resolution, using Munsell charts (Isern et al., 2002).

\section{Discussion}

\subsection{Carbonate sedimentation}

Several sedimentological indicators record significant and concurrent variations at about 6 mbsf. As indicated explicitly by the carbonate-bomb and XRD analyses, the carbonate content increases at this point. At the same level, there is a shift in the color of the sediments, from light grey to yellow/orange, supporting the use of color reflectance as a proxy for carbonate content in marine sediments (Balsam et al., 1999). The simultaneous rise in the proportion of HMC and aragonite versus LMC indicates an increased importance of platform supply, also supported by a higher amount of reefal bioclasts observed in the same core (Cotillon et al., 1994). Scattered reefs already existed throughout the Pleistocene and earlier on the Queensland and Marion Plateaus, and most likely acted as precursors to the modern GBR system (Montaggioni and Venec-Peyre, 1993). However, the large carbonate banks from the Marion Plateau have never recovered from being exposed and subsequently drowned in the middle Miocene and early Pliocene. Therefore, we interpret the simultaneous shifts in deposition style towards higher carbonate content and increased platform input as representing the onset of the southern GBR province. Although the periplatform sediments analyzed do not allow determination of the exact nature and behavior of the benthonic biota upslope, we favour the onset of one extensive carbonate factory rather than scattered reefs to explain such a considerable impact on the adjacent environment. We thus consider the initiation of the GBR as the onset of wide and semi-continuous lines of carbonate build-ups able to introduce significant changes in the sedimentation on the adjacent slope.

\subsection{Terrestrial input}

On the Australian margin, throughout the Quaternary, sediments consisted essentially of biogenic carbonates and terrigenous material, allowing carbonate records to also document variations in siliciclastic content (Dunbar and 
Nannoplankton counts for the 40 samples analyzed in Hole 1195A

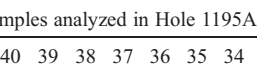

abundance

preservation

Asc. spikule

Braarudosphaera bigelowi

Calcidiscus leptoporus

Calciosolenia brasiliensi

Calciosolenia murrayi

Ceratolithus cristatus

Ceratolithus telesmus

Discosphaera tubifera

Emiliania huxleyi

Florispahera profunda

Gephyrocapsa caribbeanica L

Gephyrocapsa caribbeanica $M$

Gephyrocapsa spp.small

Gephyrocapsa oceanica M

Gephyrocapsa oceanica L

Hayaster perplexus

Helicosphaera carteri

Helicosphaera hyalina

Helicosphaera inversa

Helicosphera neorsan

Helicasphacra negranulata

Helicosphaera pavimentu

Helicosphaera wallichit

Holodiscolithus macroporus
Neosphaera coccolithomorpha

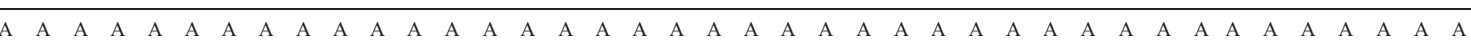

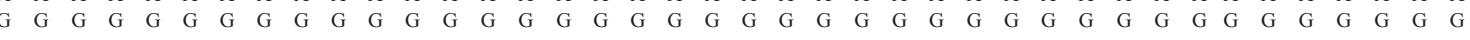
$\begin{array}{lllll}r & r & r & r \\ r & & r\end{array}$

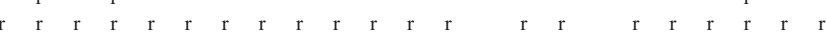

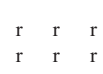

r r r r r $\begin{array}{lllllll}f / c & a & c & f / c & f / c & f / c \\ c & f / c & f / c & f / c & f / c & f / c\end{array}$

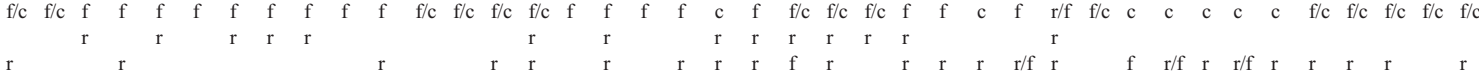

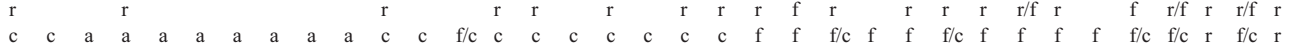

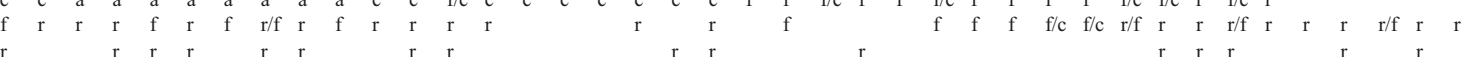

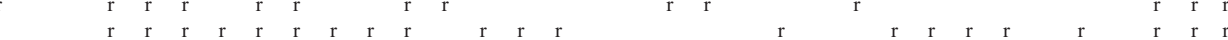

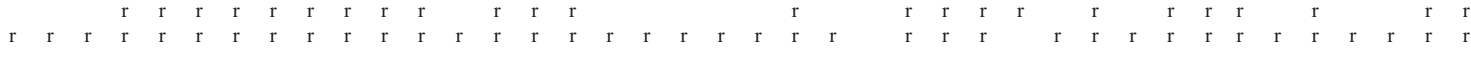
r $r$ r r r

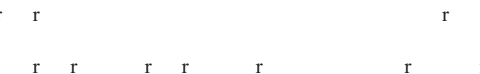


Oolithotus antillarium Oolithotus fragilis

Pontosphaera discopora

Pontosphaera japonica

Pontosphaera multipora

Pontosphaera sp.

Pseudoemiliania lacunosa

Reticulofenestra sp.

Rhabdosphaera clavigera

Rhabdosphaera sp.

Scyphosphaera aequatorialis

Scyphosphaera apsteinii

Scyphosphaera apsteinii dilatata

Scyphosphaera porosa

Syraosphaera histrica

Thoracosphera sp.

Umbellosphaera irregularis

Umbellosphaera tenuis

Umbilicosphaera hulburtiana

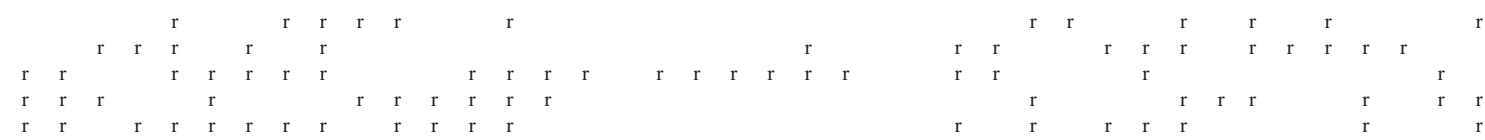

$\begin{array}{llllllllllllllllllllll}\text { Umbilicosphaera sibogae foliosa } & \mathrm{r} & \mathrm{r} & \mathrm{r} & \mathrm{r} & \mathrm{r} & \mathrm{r} & \mathrm{r} & \mathrm{r} & \mathrm{r} & \mathrm{r} & \mathrm{r} & \mathrm{r} & & \mathrm{r} & \mathrm{r} & \mathrm{r} & \mathrm{r} & \mathrm{r} & \mathrm{r} & \mathrm{r} \\ \text { Umbilicosphaera sibogae sibogae } & \mathrm{r} & \mathrm{r} & \mathrm{r} & \mathrm{r} & & & \mathrm{r} & \mathrm{r} & \mathrm{r} & & & \mathrm{r} & \mathrm{r} & \mathrm{r} & \mathrm{r} & \mathrm{r} & \mathrm{r} & \mathrm{r} & \mathrm{r} & \mathrm{r}\end{array}$

Zonation after Martini (1971) NN19 - P. lacunosa Zone

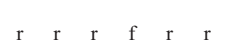

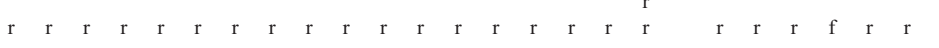

$\begin{array}{lllllllllllllllllll}r & r & r & r & r & r & r & r & r & r & r & r & r & r & & r & r & r\end{array}$

$\begin{array}{llllllllllll}r & r & r & r & & r & r & r & r & r & r\end{array}$

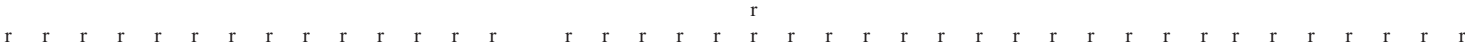

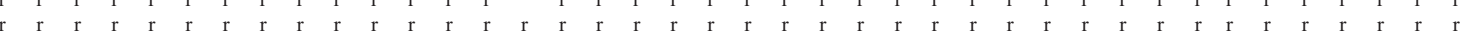
$\begin{array}{lllllll}r & \mathrm{r} & \mathrm{r} & \mathrm{r} & \mathrm{r} & \mathrm{r}\end{array}$

$\begin{array}{llllllllllllllllllllll}r & r & r & r & r & r & r & r & r & r & & r & r & r & r & r & r & r\end{array}$

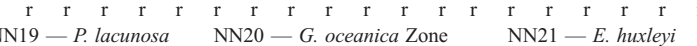
Zone Zone 

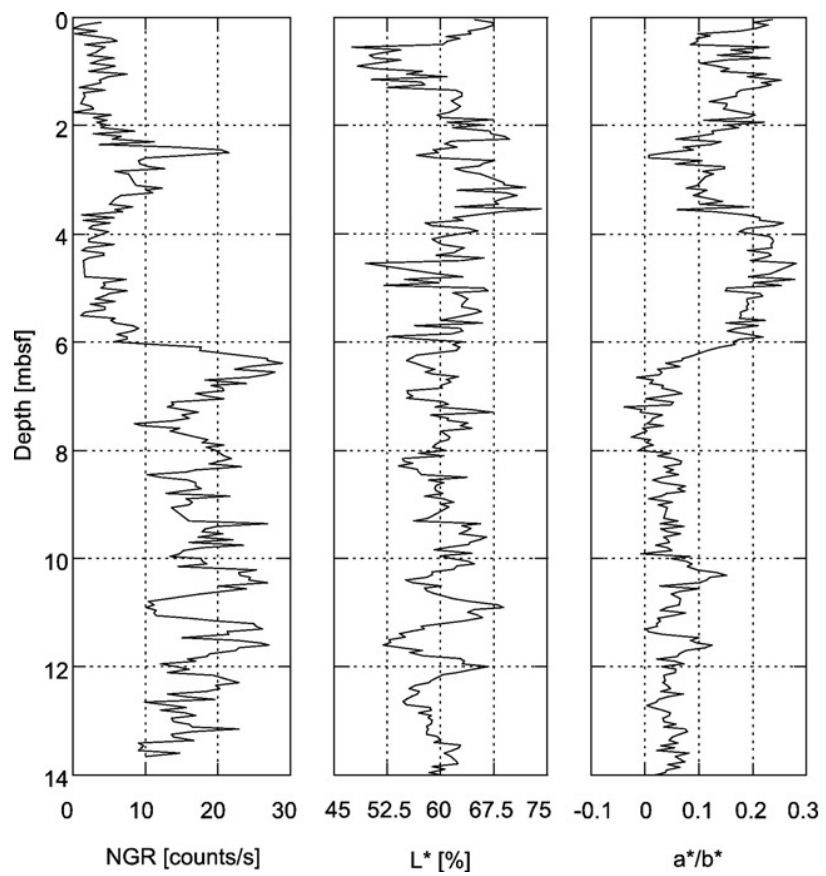

Fig. 3. Natural gamma radiation (NGR), lightness $\left(\mathrm{L}^{*}\right)$ and color reflectance parameters $(a * / b *$ ratio $)$.

Dickens, 2003). The increase in bulk carbonate content above 6 mbsf can hence be linked with a decrease in siliciclastic material. Det-P shows an upcore decline, but the shift occurs earlier than 6 mbsf (Fig. 2). Nonetheless, XRD and NGR data record the disappearance of quartz and an important reduction in clay content at 6 mbsf (Table 1 and Fig. 2). The reduction in detrital material could be explained either by a trapping of siliciclastic material by the reefs or by a carbonate production rate outweighing the delivery rate of terrigenous material. We favour the former explanation, because several studies have shown that the reefs indeed constitute topographic highs behind which siliciclastic material accumulates, notably during lowstands (Feary et al., 1993; Cotillon et al., 1994; Braithwaite et al., 2004) and because our record indicates a significant decrease in sedimentation rates at the same level (Fig. 4), as will be discussed in Section 4.4 below.

\subsection{Environmental changes}

The record of the onset of the GBR in Hole 1195A coincides also with significant changes in environmental proxies. A decrease in org-P (Fig. 2), an increase in the fraction of large grains (Fig. 2) and a decline in planktonic foraminiferal $\delta^{18} \mathrm{O}$ (Fig. 2) are recorded at $6 \mathrm{mbsf}$. We attribute the stable low values of org-P between 6 and $1.5 \mathrm{mbsf}$ as due to a restriction in the supply of organic matter from terrestrial origin by the presence of the reef barrier. The shift to coarser grain sizes corresponds to more frequent larger planktonic foraminifers, as the sediments are mostly composed of foraminiferal shells. Larger shell sizes could be the result of stronger bottom currents. Drift geometries, indicative of strong currents, are effectively distinguished on seismic data in the upper part of the drilled section (Isern et al., 2002). Because there was no barrier to shelter the Marion Plateau from the open ocean, it is reasonable to assume that current patterns on the plateau shifted and/or strengthened in response to global paleoceanographic changes (John and Mutti, 2005). However, a reduction in nutrient supply could represent an alternative explanation for the larger sizes. As demonstrated by Bé et al. (1981) and Caron et al. (1981), foraminiferal shell growth is influenced by feeding interval and light intensity. Food deprivation may result in longer life cycles and slower growth (Hemleben et al., 1989). By contrast, when nutrients are abundant, foraminifers reproduce faster and their sizes remain small. This latter explanation agrees with the reduction in terrigenous input. We are unclear as to how the variations in $\delta^{18} \mathrm{O}$ are related to the other changes. However, the fact that they appear simultaneously seems beyond coincidence.

In summary, indicators of carbonate content, carbonate mineralogy, terrestrial input and environmental parameters indicate a significant change in sedimentation, which we interpret to reflect the onset of reef growth on the southern central GBR
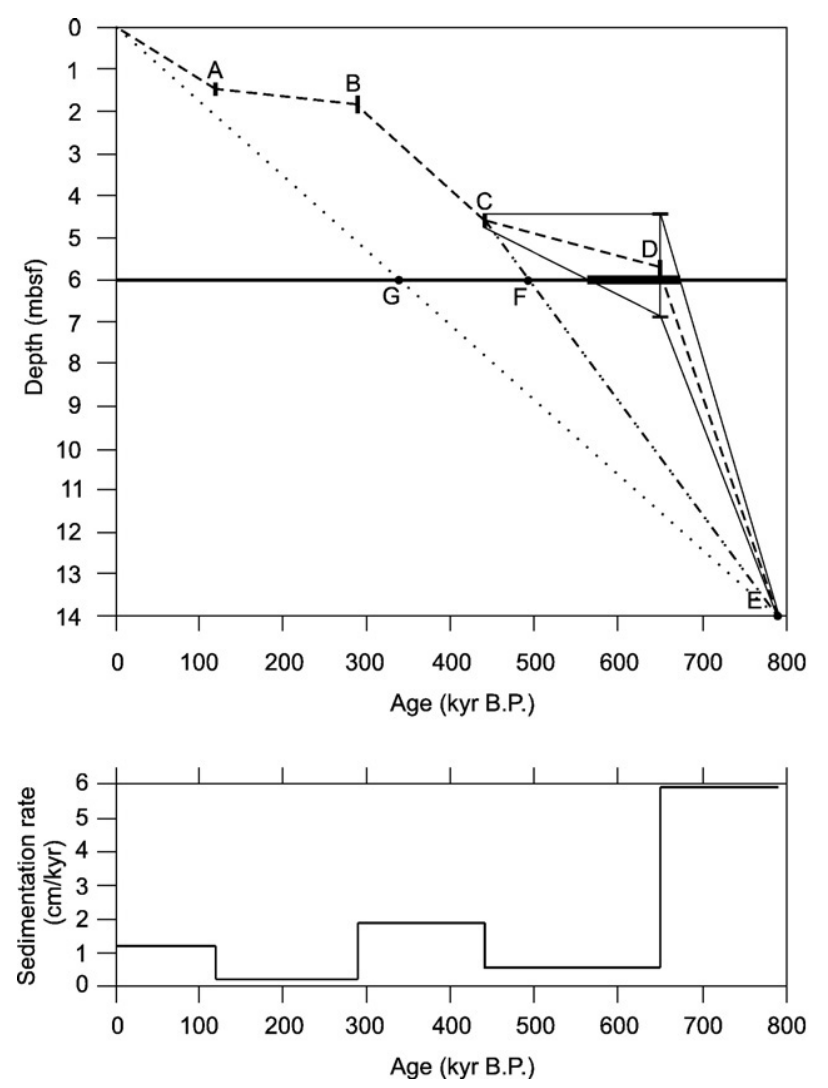

Fig. 4. Age-depth relationship and sedimentation rate at Site 1195, in black the level of major changes ( $6 \mathrm{mbs}$ ), with our best estimate for the onset of the GBR indicated by a thickening A) L.O. G. ruber pink (120 kyr B.P.) B) F.O. E. huxlei (290 kyr B.P.) C) L.O. P. lacunosa (440 kyr B.P.) D) L.O. T. tosaensis (650 kyr B.P.), with confidence interval. E) Brunhes-Matuyama magnetic reversal. F) Age obtained (500 kyr B.P.) when discarding the L.O of T. tosaensis. G) Age given (338 kyr B.P.) assuming constant sedimentation rate (see text). 
carbonate platform. In the following, we will present our age estimate for this event.

\subsection{Age model}

The age model developed for Hole 1195A is based on magnetostratigraphy and biostratigraphy (Fig. 4). The magnetic stratigraphy performed on board the Joides Resolution recorded the Brunhes-Matuyama magnetic reversal (790 kyr B.P.) at 14 mbsf (Berger et al., 1995; Isern et al., 2002). Our section thus corresponds to the Brunhes Chron. The nannofossil and planktonic foraminiferal biota provide four biohorizons, the L.O. of T. tosaensis (650 kyr B.P.) between 5.93 and 5.57 mbsf, the L.O. of P. lacunosa (440 kyr B.P.), between 4.78 and $4.42 \mathrm{mbsf}$, the F.O. of E. huxlei (290 kyr B.P.), between 2.02 and 1.62 mbsf, and the L.O. of G. ruber — pink variety (120 kyr B.P.) between 1.62 and 1.26 mbsf. The L.O. of P. lacunosa between 4.78 and 4.42 mbsf sets an upper limit for the T. tosaensis uncertainty (Fig. 4).

Although the temporal resolution of 40 samples for $790 \mathrm{kyr}$ is low, our age model is relatively well constrained for the synchronous changes at 6 mbsf, with the $\mathrm{B}-\mathrm{M}$ reversal delimiting the bottom of the section and four reliable biostratigraphic markers in the upper part (Fig. 4). We are confident in the biostratigraphic data, which are now widely used and were also employed in this region during Leg 133 (Feary et al., 1993). Moreover, some marine isotopic stages recognised could be matched with these data: In northern Australia, MIS 5 has been documented as a clear pluvial stage (Ayliffe et al., 1998), which would correspond to an increased runoff. The last occurrence of the pink variety of G. ruber in the Pacific is often used to mark the boundary between stage 6 and 5e, and its L.O. at $1.3 \mathrm{mbsf}$ in Hole 1195A coincides with an increase in terrigenous input, indicated by a shift in lightness (Fig. 3), in the $\mathrm{a}^{*} / \mathrm{b}^{*}$ ratio (Fig. 3), in clay minerals-NGR (Fig. 3), and the recovery of orgP (Fig. 2).

Assuming constant sedimentation rates between the B-M boundary and the core-top would place $6 \mathrm{mbsf}$ at $338 \mathrm{kyr}$ B.P. (point $\mathrm{G}$ in Fig. 4), an age fundamentally too young and contradicted by at least two of our biostratigraphic data. Discarding the $T$. tosaensis biostratigaphic data places our estimate for the age of this horizon at $\sim 500 \mathrm{kyr}$ B.P. (point $\mathrm{F}$ in Fig. 4). The best estimate of our age model, considering the L.O. of $T$. tosaensis with its uncertainty (i.e. whether or not we take the few specimens above 5.57 mbsf into account; Table 1), places the level of important sedimentological changes interpreted as the onset of the GBR between 560-670 kyr B.P., similar or slightly older than the ages for the onset of the GBR obtained by previous studies in more northern and proximal positions (Davies et al., 1991; Feary et al., 1993; Peerdeman et al., 1993; Davies and MacKenzie, 1993; Cotillon et al., 1994; Alexander et al., 2001; Braithwaite et al., 2004).

Fig. 4 further indicates that accumulation rates on the slope of the Marion Plateau were drastically reduced after the onset of the GBR, certainly impacted by the formation of a topographic barrier by the reef framework, trapping materials inshore.

\subsection{Controls on the GBR initiation}

Different factors have been proposed as controlling the GBR initiation. Some suggest a climatic control, with warm temperatures promoting the growth of the GBR (Davies et al., 1987; Feary et al., 1991; Peerdeman et al., 1993; Isern et al., 1996). The northward motion of the Indian-Australian plate during the Cenozoic indeed led to a transition from a subtropical to a tropical climate (Davies et al., 1987; Feary et al., 1991). The southern GBR province, which currently lies at $24^{\circ} \mathrm{S}$, was located at $50^{\circ} \mathrm{S}$ some $60 \mathrm{Myr}$ ago (Feary et al., 1991). Although the geographical transition to warmer sea surface temperatures (SSTs) was a necessary step to allow reef growth (cool temperatures inhibiting carbonate build-ups), it occurred too early to represent the factor directly controlling the onset of the GBR. Oxygen isotopic records of the compositions of the shells of foraminifera at Sites 820 and 811 indicate a progressive increase in SST throughout the late Pleistocene, interpreted as the onset of the Western Pacific Warm Pool (Peerdeman et al., 1993; Isern et al., 1996). This late increase in SST has been used to support the climate hypothesis. However, alkenone paleothermometry records only a very small increase in temperature, pointing to a potential diagenetic effect on the isotopic signal (Lawrence and Herbert, 2005). Our isotopic signal records a decrease in $\delta^{18} \mathrm{O}$ values only since $4 \mathrm{mbsf}(\sim 400 \mathrm{kyr}$ B.P.).

A second hypothesis is based on the shift in frequency of the dominant Milankovitch cycles, from $40 \mathrm{kyr}$ to $100 \mathrm{kyr}$, at the midPleistocene Revolution (MPR Larcombe and Carter, 2004). Subsequent reef development was encouraged by higher and longer highstands, resulting in wider and deeper shelves. However, the timing of the MPR remains controversial. Some suggest a rapid change at $\sim 900$ kyr B.P. (Maasch, 1988) or at $\sim 700$ kyr B.P. (MIS 17) (Berger and Jansen, 1994), while others propose a gradual mid-Pleistocene climate transition (860450 kyr B.P.) (Hall et al., 2001). Peerdeman et al. (1993) attributed an age of $400 \mathrm{kyr}$ to the shift in frequency of the $\delta^{18} \mathrm{O}$ record from Site 820 that seems too young to be correlated with the MPR. The significant changes in sedimentation rates at our site and the low sampling resolution do not allow us to study changes in the frequency of the $\delta^{18} \mathrm{O}$ record. However, our inferred age for the onset of the GBR would agree with the MPR as proposed by Berger and Jansen (1994), around 700 kyr B.P., but with a gradual climate transition (Hall et al., 2001).

The last hypothesis considers eustatic sea level fluctuations as the most crucial element for reefal development. A recent hypothesis suggests that the high amplitude sea-level rise at the transition from glacial MIS 12 to interglacial MIS 11 (420 kyr B.P.), associated with warm SST and the unusually long duration of MIS 11 (>30 kyr) triggered a global and synchronous establishment of modern barrier reefs (Droxler et al., 1997; Droxler and Farrell, 2000). This hypothesis is supported by studies favoring development of the GBR around 400-500 kyr B.P. (Peerdeman et al., 1993; Davies and MacKenzie, 1993; Cotillon et al., 1994; Braithwaite et al., 2004), but not by our research or those favoring an older initiation (600-900 kyr B.P.) (Davies et al., 1991; Feary et al., 1993; Alexander et al., 2001). 


\section{Conclusions}

The purpose of this study was to evaluate if and how the onset of the GBR was recorded in more distal environments, such as the Marion Plateau. Based on a detailed examination of proxy variations in the upper part of Hole 1195A, we draw the following conclusions:

1. The initiation of the GBR represents a major paleoceanographic change, which is undeniably recorded in distal sediments of the north-eastern Australian continental margin.

2. The most commonly used proxies are affected by this initiation that leads either to an irreversible modification of the mean value of the proxy or to a shift in the amplitude and/ or frequency of the signal.

3. The initiation of the GBR is primarily indicated in distal locations by an increase in the proportion of sediment of platform origin. At Site 1195, the sediments become richer in carbonates, in particular HMC and aragonite, and contain more bioclasts. In addition, the sediments become yellower.

4. At Site 1195, the onset of the GBR is accompanied by a reduction in input of terrigenous siliciclastic material and organic matter, related to the formation of a topographic barrier by the reef framework, trapping materials inshore. XRD analyses record the disappearance of quartz, and NGR shows an important decrease in clay content at $6 \mathrm{mbsf}$. Phosphorus associated with organic matter decreases between 6 and 1.5 mbsf. A higher proportion of large foraminiferal shells seems to indicate a reduction in nutrients, but could also be the result of intensified bottom currents.

5. As already indicated by previous research, the onset of reefal frameworks greatly reduces the rate of deposition of sediments in distal environments.

6. Based on our age model, we propose that the southern province of the GBR initiated between 560 and $670 \mathrm{kyr}$ B.P.

7. Although this study has insufficient resolution, it clearly indicates the potential of distal sediments to record changes on adjacent carbonate platforms, notably their initiation. A higher resolution study could provide a solution to the dating problems pertaining to the onset of the GBR. We suggest that subsequent research intending to study this important event should focus on distal environments that record more continuous deposition and represent larger source areas.

\section{Acknowledgments}

We thank Bernard Grobéty, Frederica Tamburini and Torsten Vennemann for their help in laboratory measurements. We are grateful to Elizabeth Shadwick and Markus Kienast for their welcome constructive remarks on an early version of the manuscript. This manuscript benefited from critical reviews from C.J.R. Braithwaite and an anonymous reviewer. Samples and data were provided by the Ocean Drilling Program. ODP is sponsored by the U.S. National Science Foundation (NSF) and participating countries under management of Joint Oceanographic Institutions (JOI), Inc. Analytical facilities were provided by the Earth Sciences Section of the University of Geneva, the
Geological Institute of the University of Fribourg, the University of Lausanne and the ETH Stable Isotope Laboratory of Zürich.

\section{References}

Alexander, I., Andres, M.S., Braithwaite, C.J.R., Braga, J.C., Cooper, M.J., Davies, P.J., Elderfield, H., Gilmour, M.A., Jay, R.L.F., Kroon, D., McKenzie, J.A., Montaggioni, L.F., Skinner, L.F., Thompson, R., Vasconcelos, C., Webster, J., Wilson, P.A., International Consortium for Great Barrier Reef Drilling, 2001. New constraints on the origin of the Australian Great Barrier Reef: results from an international project of deep coring. Geology 29, 483-486.

Anderson, L.D., Delaney, M.L., 2000. Sequential extraction and analysis of phosphorus in marine sediments: streamlining of the SEDEX procedure. Limnol. Oceanogr. 45, 509-515.

Ayliffe, L.K., Marianelli, P.C., Moriarty, K.C., Wells, R.T., McCulloch, M.T., Mortimer, G.E., Hellstrom, J.C., 1998. 500 ka precipitation record from south eastern Australia: Evidence for interglacial relative aridity. Geology 26, $147-150$.

Balsam, W.L., Deaton, B.C., Damuth, J.E., 1999. Evaluating optical lightness as a proxy for carbonate content in marine sediment cores. Mar. Geol. 161, $141-153$

Bé, A.W.H., Caron, D.A., Anderson, O.R., 1981. Effects of feeding frequency on life processes of the planktonic foraminifer Globigerinoides sacculifer in laboratory cultures. J. Mar. Biol. Assoc. U.K. 61, 257-277.

Berger, W.H., Jansen, E., 1994. Mid-Pleistocene climate shift: the Nansen connection. In: Johansen, O.M., et al. (Ed.), The polar oceans and their role in shaping the global environment. Geophys. Monograph Ser., vol. 32. Am. Geoph. U., Washington, DC, pp. 295-311.

Berger, W.H., Bickert, T., Wefer, G., Yasuda, M.K., 1995. Brunhes-Matuyama boundary: $790 \mathrm{k} . \mathrm{y}$. date consistent with ODP Leg 130 oxygen isotope records based on fit to Milankovitch template. Geophys. Res. Lett. 22, 1525-1528.

Berggren, W.A., Hilgen, F.J., Langereis, C.G., Kent, D.V., Obradovich, J.D., Raffi, I., Raymo, M.E., Shackleton, N.J., 1995. Late Neogene chronology: new perspectives in high resolution stratigraphy. Geol. Soc. Amer. Bull. 107, $1272-1287$.

Braithwaite, C.J.R., Dalmasso, H., Gilmour, M.A., Harkness, D.D., Henderson, G.M., Kay, R.L.F., Kroon, D., Montaggioni, L.F., Wilson, P.A., 2004. The Great Barrier Reef: The chronological record from a new borehole. J. Sediment. Res. 74, 298-310.

Caron, D.A., Bé, A.W.H., Anderson, O.R., 1981. Effects of variations in light intensity on life processes of the planktonic foraminifer Globigerinoides sacculifer in laboratory cultures. J. Mar. Biol. Assoc. U.K. 62, 435-452.

Cotillon, P., Rousselle, B., Courtinat, B., Crumiere, J.-P., 1994. Evolution of sediment fluxes from the Middle Miocene to present at ODP Site 817 (Townsville Basin, northeastern Australia) as a record of regional paleoceanographic events. Mar. Geol. 121, 265-291.

Davies, P.J., McKenzie, J.A., 1993. Controls on the Pliocene-Pleistocene evolution of the northeastern Australian continental margin. In: McKenzie, J.A., Davies, P.J., Palmer-Julson, A., et al. (Eds.), Proceedings of the Ocean Drilling Program. Scientific Results, vol. 133. Ocean Drilling Program, College Station, TX, pp. 755-762.

Davies, P.J., Symonds, P.A., Feary, D.A., Pigram, C.J., 1987. Horizontal plate motion: a key allocyclic factor in the evolution of the Great Barrier Reef. Science 238, 1697-1699.

Davies, P.J., McKenzie, J.A., Palmer-Julson, A., et al., 1991. Proceedings of the Ocean Drilling Program. Initial Reports, vol. 133. Ocean Drilling Program, College Station, TX. 810 pp.

Droxler, A.W., Farrell, J.W., 2000. Marine Isotope Stage 11 (MIS 11): new insights for warm future. Glob. Planet. Change 24, 1-5.

Droxler, A.W., Ferro, E.C., Mucciarone, D.A., Haddad, G.A., 1997. The marine carbonate system during oxygen isotope stage 11 (423-362 ka): a case of basin to shelf and/or basin-to-basin carbonate fractionation? EOS Trans. AGU 78 (17), 179.

Dunbar, G.B., Dickens, G.R., 2003. Massive siliciclastic discharge to slopes of the Great Barrier Reef Platform during sea-level transgression: constraints from sediment cores between $15^{\circ} \mathrm{S}$ and $16^{\circ} \mathrm{S}$ latitude and possible explanations. Sediment. Geol. 162, 141-158. 
Feary, D.A., Davies, P.J., Pigram, C.J., Symonds, P.A., 1991. Climatic evolution and control on carbonate deposition in northeast Australia. Palaeogeogr. Palaeoclimatol. Palaeoecol. 89, 341-361.

Feary, D.A., Symonds, P.A., Davies, P.J., Pigram, G.J., Jarrard, R.D., 1993. Geometry of Pleistocene facies on the Great Barrier Reef outer shelf and upper slope-seismic stratigraphy of Sites 819, 820 and 821. In: McKenzie, J.A., Davies, P.J., Palmer-Julson, A., et al. (Eds.), Proceedings of the Ocean Drilling Program. Scientific Results, vol. 133. Ocean Drilling Program, College Station, TX, pp. 327-343.

Hall, I.R., McCave, I.N., Shackleton, N.J., Weedon, G.P., Harris, S.E., 2001. Intensified deep Pacific inflow and ventilation in Pleistocene glacial times. Nature 412, 809-812.

Hemleben, C., Spindler, M., Anderson, O.R., 1989. Modern planktonic foraminifera. Springer Verlag, Berlin. 363pp.

Isern, A.R., McKenzie, J.A., Feary, D.A., 1996. The role of sea-surface temperature as a control on carbonate platform development in the western Coral Sea. Palaeogeogr. Palaeoclimatol. Palaeoecol. 124, 247-272.

Isern, A.R., Anselmetti, F.S., Blum, P., 2002. Constraining Miocene sea level change from carbonate platform evolution, Marion Plateau, Northeast Australia, Sites 1192-1199, 3 January-2 March 2001. Proceedings of the Ocean Drilling Program. Initial Reports, vol. 194. Ocean Drilling Program, College Station, TX. 88 pp.

John, C.M., Mutti, M., 2005. Relative control of paleoceanography, climate, and eustasy over heterozoan carbonates: a perspective from slope sediments of the Marion Plateau (ODP Leg 194). J. Sediment. Res. 75, 216-230.

Kindler, P., Ruchonnet, C., White, T., 2006. The Southern Marion Platform (Marion Plateau, NE Australia) during the early Pliocene: a lowstandproducing, temperate water carbonate factory. In: Pedley, H.M., Carannante, G. (Eds.), Cool-water carbonates: depositional systems and palaeoenvironmental control. Geol. Soc. London Spec. Publ., vol. 255, pp. 271-284.

Larcombe, P., Carter, R.M., 2004. Cyclone pumping, sediment partitioning and the development of the Great Barrier Reef shelf system: a review. Quat. Sci. Rev. 23, 107-135.

Lawrence, K.T., Herbert, T.D., 2005. Late Quaternary sea-surface temperatures in the western Coral Sea: Implications for the growth of the Australian Great Barrier Reef. Geol. Soc. Am. 33, 677-680.

Lourens, L., Hilgen, F., Shackleton, N.J., Laskar, J., Wilson, J., 2004. Orbital tuning calibrations and conversions for the Neogene Period. In: Gradstein, F.,
Ogg, J., Smith, A. (Eds.), A geologic time scale 2004. Cambridge University Press, Cambridge, pp. 469-484.

Maasch, K.A., 1988. Statistical detection of the mid Pleistocene transition. Clim. Dyn. 2, 133-143.

Martini, E., 1971. Standard Tertiary and Quaternary calcareous nannoplankton zonation. Proceedings of the second planktonic conference Roma 1970. Edizioni Tecnoscienza, Rome, pp. 739-785.

Montaggioni, L.F., Venec-Peyre, M.-T., 1993. Shallow-water foraminiferal taphocenoses at Site 821: implications for the Pleistocene evolution of the central Great Barrier Reef shelf, Northeastern Australia. In: McKenzie, J.A., Davies, P.J., Palmer-Julson, A., et al. (Eds.), Proceedings of the Ocean Drilling Program. Scientific Results, vol. 133. Ocean Drilling Program, College Station, TX, pp. 365-377.

Müller, G., Gastner, M., 1971. The "Karbonat-Bombe", a simple device for the determination of the carbonate content in sediments, soils and other materials. Neues Jahrb. Mineral. Abh. 10, 466-469.

Page, M.C., Dickens, G.R., 2005. Sediment fluxes to Marion Plateau (southern Great Barrier Reef province) over the last $130 \mathrm{ky}$ : new constraints on «transgressive-shedding» off northeastern Australia. Mar. Geol. 219, 27-45.

Peerdeman, F.M., Davies, P.J., Chivas, A.R., 1993. The stable isotope signal in shallow-water, upper slope sediments off the Great Barrier Reef (Holes 820A). In: McKenzie, J.A., Davies, P.J., Palmer-Julson, A., et al. (Eds.), Proceedings of the Ocean Drilling Program. Scientific Results, vol. 133. Ocean Drilling Program, College Station, TX, pp. 163-173.

Ruttenberg, K.C., 1992. Development of a sequential extraction method for different forms of phosphorus in marine sediments. Limnol. Oceanogr. 37, 1460-1482.

Taylor, J.C., 1991. Computer programs for standardless quantitative analysis of minerals using the full powder diffraction profile. Powder Diffr. 6, 2-9.

Thompson, P.R., Bé, A.W.H., Duplessy, J.-C., Shackleton, N.J., 1979 Disappearance of pink-pigmented Globigerinoides ruber at 120,000 $\mathrm{yr}$ BP in the Indian and Pacific Oceans. Nature 280, 554-558.

Webster, J.M., Davies, P.J., 2003. Coral variation in two deep drill cores: significance for the Pleistocene development of the Great Barrier Reef. Sediment. Geol. 159, 61-80 